\title{
Pengaruh Persalinan Terhadap Penurunan Kadar Hb Pada Ibu Bersalin di Rumah Sakit Umum Daerah Budhi Asih Jakarta Timur Tahun 2016
}

\section{The influence of labor to the decline in maternal Hb levels in B udhi Asih Hospital in East J akarta in 2016}

\author{
Dina Arihta, Utami Femina Sari \\ STIKes Mitra RIA Husada
}

Korespondensi Email: ditabayu26@gmail.com, 081289356414

\begin{abstract}
Abstrak
Kadar hemoglobin bisa menunjukkan keadaan anemia atau tidak. Prevalensi anemia ibu hamil di Indonesia cukup tinggi. Anemia merupakan salah satu penyebab kematian ibu tidak langsung yang disebabkan oleh defisiensi besi dan perdarahan akut bahkan tidak jarang keduanya saling berinteraksi. Anemia merupakan hal penting untuk diperhatikan guna menurunkan angka kematian ibu pasca persalinan di Indonesia. Penelitian ini bertujuan untuk mengetahui pengaruh persalinan terhadap penurunan kadar $\mathrm{Hb}$ pada ibu bersalin berdasarkan jenis persalinan dan (IMT). Desain penelitian yang digunakan adalah one-group pretest-posttest desain penelitian yang dilaksanakan pada satu kelompok saja tanpa kelompok pembanding. Sampel penelitian yang di ambil adalah sebanyak 91 responden. Hasil penelitian didapatkan bahwa rata-rata $\mathrm{Hb}$ sebelum persalinan adalah $11.62 \mathrm{gr} \%$ dan rata-rata $\mathrm{Hb}$ sesudah persalinan adalah $11.01 \mathrm{gr} \%$. Ada pengaruh yang signifikan antara jenis persalinan dengan penurunan kadar $\mathrm{Hb}$ dan tidak ada pengaruh yang signifikan antara nilai IMT dengan penurunan kadar $\mathrm{Hb}$. Temuan ini diharapkan dapat menjadi rujukan ibu hamil untuk mengkonsumsi tablet $\mathrm{Fe}$ dan mengkonsumsi makanan yang bergizi seimbang, meningkatkan efektifitas konseling individual mengenai anemia dan penyebabnya kepada ibu hamil.
\end{abstract}

Kata kunci : penurunan kadar Hb, jenis persalinan, IMT.

\section{Abstract}

Hemoglobin levels can indicate anemia. Prevalence of anemia among pregnant women in Indonesia is quite high. Anemia is one of the indirect causes of maternal death caused by iron deficiency and acute bleeding is not uncommon even the two interact. Anemia is an important thing to note in order to reduce maternal mortality postpartum in Indonesia. This study aimed to determine the effect of labor in the decline of maternal $\mathrm{Hb}$ level based on the type of labor and base mass index (BMI). The study design is one-group pretest-posttest design study carried out in a single group without a comparison group. The research sample involved 91 respondents. The result showed that the average $\mathrm{Hb}$ before delivery was $11.62 \mathrm{~g} \%$ and after childbirth was $11.01 \mathrm{gr} \%$. There was a significant relationship between the type of delivery with a decrease in hemoglobin level and no significant relationship between BMI values with a decrease in hemoglobin concentration. This study 
is expected to remind pregnant women to consume iron tablet and consuming foods that are nutritionally balanced,and to increase the effectiveness of individual counseling about anemia and its cause pregnant women.

Keywords : decrease Hb, type labor, BMI

\section{Pendahuluan}

Angka kematian ibu (AKI) atau Maternal Mortality Rate (MMR) merupakan indikator yang digunakan untuk mengukur status kesehatan ibu pada suatu wilayah. World Health Organization (WHO) memperkirakan terdapat 216 kematian ibu setiap 100.000 kelahiran hidup akibat komplikasi kehamilan dan persalinan tahun 2015. Indonesia termasuk salah satu negara berkembang sebagai penyumbang tertinggi angka kematian ibu di dunia. WHO memperkirakan di Indonesia terdapat sebesar 126 kematian ibu setiap 100.000 kelahiran hidup dengan jumlah total kematian ibu sebesar 6400 pada tahun 2015.

Kadar hemoglobin bisa menunjukkan keadaan anemia atau tidak. Prevalensi anemia ibu hamil di Indonesia cukup tinggi. Anemia merupakan salah satu penyebab kematian ibu tidak langsung yang disebabkan oleh defisiensi besi dan perdarahan akut bahkan tidak jarang keduanya saling berinteraksi. Anemia merupakan hal penting untuk diperhatikan guna menurunkan angka kematian ibu pasca persalinan di Indonesia (Prawirohardjo, 2012).

Masa nifas disebut juga masa post partum atau puerperium adalah masa atau waktu sejak bayi dilahirkan dan plasenta keluar lepas dari rahim, sampai enam minggu berikutnya, disertai dengan pulihnya kembali organ-organ yang berkaitan dengan kandungan, yang mengalami perubahan seperti perlukaan dan lain sebagainya berkaitan saat melahirkan (Sulistya,
2009). Menurut laporan WHO di dunia terdapat 273,2 juta orang mengalami anemia tahun 2011. Angka kejadian anemia pada ibu nifas di dunia sekitar 38,2 juta jiwa. Sedangkan di Asia Tenggara terdapat 22,3 juta jiwa yang mengalami anemia dan angka kejadian anemia pada ibu nifas 11,5 juta. Prevalensi kejadian anemia di Asia yaitu 39,3\%. Sedangkan di Indonesia prevalensi anemia sekitar 30\%.

Anemia pada masa nifas adalah suatu keadaan dimana seorang ibu sehabis melahirkan sampai dengan kira-kira 6 minggu dalam kondisi pucat, lemah, dan kurang bertenaga. Anemia dalam masa nifas adalah lanjutan dari anemia yang diderita pada saat kehamilan, yang menyebabkan banyak keluhan bagi ibu dan mengurangi presentasi kerja. Baik dalam pekerjaan rumah sehari-hari ataupun merawat bayi. Penyebab anemia pada masa nifas adalah persalinan dengan perdarahan, ibu hamil dengan anemia, nutrisi yang kurang, virus dan bakteri. Pengaruh anemia pada masa nifas adalah terjadinya subinvolusi uteri yang dapat menimbulkan perdarahan post partum, memudahkan infeksi puerperium, pengeluaran ASI berkurang dan mudah terjadi infeksi mamae (Prawirohardjo, 2012).

Indeks massa tubuh (IMT) merupakan indikator status gizi seseorang. Status gizi ibu sangat penting untuk tercapainya kesejahteraan ibu dan janin. Wanita dengan status gizi rendah, memiliki efek negatif pada proses persalinannya karena kekurangan gizi sebagai penyebab 
anemia. Anemia dapat mengganggu kekuatan mengejan sehingga ibu menjadi lemah dan dapat memperlambat persalinan sehingga harus dibantu dengan tindakan operasi, selain itu anemia dapat menyebabkan perdarahan post partum dikarenakan pada kondisi ibu dengan anemia dapat menyebabkan kala III berlangsung lama sehingga menjadi penyebab perdarahan post partum (Sativa, 2011).

Subinvolusi adalah kegagalan uterus untuk mengikuti pola normal involusi, dan keadaan ini merupakan salah satu dari penyebab terumum perdarahan post partum. Perdarahan hebat merupakan penyebab tersering anemia. Jika perdarahan ini berlangsung terus menerus lalu menjadi perdarahan hebat, maka akan kehilangan sejumlah besar darah, terkurasnya cadangan zat besi dalam tubuh yang membuat pembentukan sel darah merah terganggu, sehingga menjadikan uterus tidak berkontraksi dengan baik dan lembek, lalu tekanan darah menurun karena jumlah cairan didalam pembuluh darah berkurang, pasokan oksigen tubuh menurun karena jumlah sel darah merah yang mengangkut oksigen berkurang sehingga darah lama berhenti dan ibu menjadi terus-menerus letih dan menyebabkan daya tahan tubuh menurun sehingga mudah sekali terkena infeksi, dalam hal ini adalah infeksi puerperium, lalu mempengaruhi faktor psikis dan emosionalnya sehingga dapat mempengaruhi produksi ASI untuk bayinya (Prawirohardjo, 2012).

Berdasarkan hasil penelitian yang dilakukan di Universitas Diponegoro Semarang menyatakan bahwa persalinan normal berada pada kategori IMT normal sebanyak $46,6 \%$ dan persalinan Caesar pada kategori IMT underweight sebanyak $28,6 \%$. Hasil penelitian yang dilakukan di Universitas Negeri Semarang menyatakan bahwa Persalinan normal dengan anemia sebanyak $21,7 \%$ dan persalinan caesar sebanyak $78,3 \%$.

RSUD Budhi Asih merupakan salah satu dari rumah sakit di wilayah Jakarta Timur di RSUD Budhi Asih ini masih banyak ibu post partum yang mengalami anemia, jika kita lihat dari data rekam medik dalam 10 bulan terakhir ini sudah ada 158 pasien yang melakukan transfusi darah dari 1950 pasien bersalin, sedangkan yang anemia sebanyak 45,3\%. Berdasarkan fakta tersebut menjadi alasan dilakukan penelitian tentang pengaruh persalinan terhadap penurunan kadar $\mathrm{Hb}$ pada ibu bersalin di RSUD Budhi Asih Jakarta Timur tahun 2016

\section{Bahan dan Metoda Penelitian}

Penelitian ini adalah penelitian survey yang bersifat analitik kuantitatif. Desain penelitian yang digunakan adalah one-group pretest-posttest yaitu desain penelitian yang dilaksanakan pada satu kelompok saja tanpa kelompok pembanding (Sugiyono, 2007). Pada desain ini penelitian dilakukan sebanyak dua kali, pengukuran pertama dilakukan didepan (pretest) sebelum adanya perlakuan (treatment) dan pengukuran yang kedua (posttest) dilakukan setelah diberikan perlakuan atau intervensi.

Penelitian ini dilakukan di Rmah Sakit Umum Daerah Budhi Asih yang berlokasi di JI . Dewi Sartika Cawang III/200 Jakarta Timur, sedangkan waktu penelitian sampai dengan penyusunan laporan hasil penelitian dilaksanakan bulan Januari - Juni tahun 2016.

Populasi keseluruhan dari penelitian ini adalah seluruh ibu bersalin pada tanggal 01 Januari - 30 Juni tahun 2016, di Rumah Sakit Umum Daerah Budhi Asih Jakarta Timur tahun 2016 yang berjumlah 983 ibu bersalin. Sampel merupakan bagian dari populasi yang diambil 
untuk penelitian yang dapat mewakili populasi yang dibutuhkan (Sugiyono, 2007). Maka jumlah sampel tersebut adalah 91 orang.

Penelitian untuk data responden dilakukan dengan melihat instrument penelitian yaitu data rekam medik pasien dalam proses pengumpulan data. Pengumpulan data skunder dilakukan dengan cara melihat langsung data rekam medik ibu bersalin. Data yang telah dikumpulkan diolah dan dianalisis dengan system komputerisasi program SPSS melalui coding, editing ,entryng, cleaning serta analisi data dan disajikan dalam bentuk tabel dan narasi.

\section{Hasil Penelitian}

Hasil analisis univariat numerik diketahui rata-rata $\mathrm{Hb}$ sebelum persalinan adalah 11.62 gr\% $(95 \% \mathrm{Cl}: 11.41-11.84)$, dengan standar deviasi 1.033. $\mathrm{Hb}$ terendah $9.20 \mathrm{gr} \%$ dan $\mathrm{Hb}$ tertinggi $13.80 \mathrm{gr} \%$. Diketahui nilai tengah dari $\mathrm{Hb}$ sebelum bersalin adalah $11.50 \mathrm{gr} \%$, dan $\mathrm{Hb}$ sesudah bersalin adalah $11.00 \mathrm{gr} \%$. Dari hasil estimasi interval dapat disimpulkan bahwa 95\% diyakini bahwa rata-rata $\mathrm{Hb}$ ibu sebelum bersalin adalah diantara 11.41 sampai dengan 11.84 gr\%. Kemudian diketahui juga rata-rata $\mathrm{Hb}$ sesudah persalinan adalah $11.01 \mathrm{gr} \%(95 \% \mathrm{Cl}$ : 10.80-11.22), dengan standar deviasi 1.014. $\mathrm{Hb}$ terendah $8.20 \mathrm{gr} \%$ dan $\mathrm{Hb}$ tertinggi $13.20 \mathrm{gr} \%$. Dari hasil estimasi interval dapat disimpulkan bahwa 95\% diyakini bahwa rata-rata $\mathrm{Hb}$ ibu sesudah bersalin adalah 10.80 sampai dengan 11.22 gr\%. Kategorik : dimana sebagian besar jenis persalinan adalah persalinan normal yaitu sebanyak $52.7 \%$, sebagian besar IMT adalah tidak normal yaitu sebanyak $85.7 \%$.

Hasil analisis bivariat diketahui rata-rata kadar $\mathrm{Hb}$ ibu sebelum bersalin adalah adalah 11.62 gr\% dengan standar deviasi 1.033 gr\% dan standar error $0.108 \mathrm{gr} \%$. Setelah bersalin rata-rata penurunan kadar $\mathrm{Hb}$ ibu menjadi 11.01 gr\% dengan standar deviasi 1.014 gr\% dan standar error $0.106 \mathrm{gr} \%$. Terlihat nilai mean perbedaan antara sebelum dan sesudah bersalin adalah $0.61 \mathrm{gr} \%$ dengan standar deviasi 0.019 gr\% dan standar error 0.002 gr\%, sehingga dapat kita ketahui bahwa $\mathrm{Hb}$ sebelum dan sesudah bersalin memang mengalami penurunan. Hasil uji statistik didapatkan nilai $P$ Value 0.000 maka dapat disimpulkan ada pengaruh yang signifikan antara pengaruh persalinan terhadap penurunan kadar $\mathrm{Hb}$.

Dari penelitian ini diketahui persalinan sectio caesaria adalah $0.618 \mathrm{gr} \%$ dengan standar deviasi $0.598 \mathrm{gr} \%$ dan standar error 0.091 gr\%. Sedangkan persalinan normal 0.614 gr\% dengan standar deviasi 0.614 gr\% dan standar error mean $0.041 \mathrm{gr} \%$. Nilai rata-rata antara persalinan section caesaria dan persalinan normal adalah $0.004 \mathrm{gr} \%$ dengan standar deviasi 0.314 gr $\%$ dan standar error 0.05 gr\%. Hasil uji statistik didapatkan nilai $p=0.026$ maka dapat disimpulkan ada pengaruh yang signifikan antara jenis persalinan dengan penurunan kadar $\mathrm{Hb}$.

Dari penelitian diketahui nilai rata-rata perbedaan IMT yang tidak normal adalah 0.597 $\mathrm{kg} / \mathrm{m} 2$ dengan standar deviasi $0.472 \mathrm{~kg} / \mathrm{m} 2$ dan standar error 0.053 sedang IMT yang normal $0.730 \mathrm{~kg} / \mathrm{m} 2$ dengan standar deviasi $0352 \mathrm{~kg} / \mathrm{m} 2$ dan standar error mean 0.097 . Selisih nilai ratarata perbedaan antara nilai IMT yang tidak normal dan nilai IMT yang normal adalah -0.133 $\mathrm{kg} / \mathrm{m} 2$ dengan standar deviasi $0.12 \mathrm{~kg} / \mathrm{m} 2$ dan standar error -0.044 gr\%. Hasil uji statistik didapatkan nilai $\mathrm{p}=0.768$ maka dapat disimpulkan tidak ada pengaruh yang signifikan antara nilai IMT dengan penurunan kadar $\mathrm{Hb}$. 


\section{Diskusi}

Penelitian tentang penurunan kadar $\mathrm{Hb}$ telah banyak dilakukan, berikut ini beberapa penelitian lain tentang penurunan kadar $\mathrm{Hb}$ yang pernah dilakukan, antara lain: Mika (2012), yang berjudul hubungan antara anemia dengan ibu bersalin di RB L tahun 2012. Sarbaini (2010), yang berjudul faktor-faktor yang berhubungan persalinan Sectio Caesaria di RS IYG tahun 2010. Sri Wahyuni (2010), yang berjudul hubungan anemia dengan kejadian persalinan premature di RS P tahun 2010. Yanti (2009), yang berjudul pengaruh IMT pada wanita saat hamil terhadap pola makan di RSUP dr. $\mathrm{K}$ tahun 2009. Hal ini sesuai dengan teori Tarwoto (2012) bahwa setiap wanita melahirkan pasti mengeluarkan darah. Berapa banyaknya tergantung lama persalinan. Itulah sebabnya semua ibu setelah melahirkan pasti terlihat pucat dan kelelahan. Itu karena mereka kekurangan darah. Masalahnya apabila Hemoglobin $(\mathrm{Hb})$ ibu turun terus, maka sebaiknya ibu juga harus berhati-hati saat akan melahirkan. Penelitian ini juga sesuai dengan penelitian yang dilakukan oleh Sarbaini (2010) bahwa persalinan mempunyai hubungan dengan penurunan kadar $\mathrm{Hb}$, tetapi berbeda dengan penelitian yang dilakukan oleh Sri Wahyuni (2010) bahwa persalinan tidak ada hubungan yang signifikan dengan kadar $\mathrm{Hb}$. Kelancaran proses persalinan sangat ditentukan oleh kecukupan hemoglobin dalam darah, bila penurunan kadar $\mathrm{Hb}$ terus berlanjut dapat mempersulit proses persalinan. dapat menghambat metabolisme tubuh dalam merespon hormon-hormon yang berperan dalam proses persalinan. Akibatnya, pembukaan berjalan lambat atau terhambat, otot rahim lelah berkontraksi, gangguan his, dan tidak adanya kontraksi rahim yang menjadikan proses persalinan berjalan lama. Jika persalinan berlangsung lama maka akan terjadi perdarahan, bila terus menerus terjadi dan tidak berhenti maka kadar $\mathrm{Hb}$ ibu dapat terus turun karena kadar Hemoglobin $(\mathrm{Hb})$ yang rendah bisa membahayakan apabila terjadi perdarahan. Selama persalinan terjadi aktivitas yang berat dan mengeluarkan banyak tenaga, oksigen yang tersimpan akan digunakan dengan cepat dan sirkulasi darah normal tidak dapat menyuplai oksigen dengan baik sehingga kinerja otot akan kehabisan oksigen yang menyebabkan keletihan otot untuk berkontraksi.

Dari penelitian diketahui ada pengaruh yang signifikan antara jenis persalinan dengan penurunan kadar $\mathrm{Hb}$. Hal ini sesuai dengan teori menurut Manuaba (2011) Penurunan kadar Hb dapat memberikan pengaruh buruk terhadap ibu maupun janin yang dikandungnya, seperti Gangguan his kekuatan mengejan. Kala I dan kala II yang lama dapat melelahkan dan sering menimbulkan tindakan operasi dan kala urin dapat disertai dengan retensio plasenta, dan perdarahan post partum oleh karena itu diperlukan pemeriksaan kadar $\mathrm{Hb}$ secara rutin selama kehamilan. Penelitian ini juga sesuai dengan hasil penelitian Sarbaini (2010) bahwa ibu dengan kadar $\mathrm{Hb}$ yang rendah akan mengalami persalinan section caesaria tiga kali lebih besar dari pada ibu yang memiliki kadar $\mathrm{Hb}$ normal. Hasil penelitian ini juga sama dengan hasil penelitian yang dilakukan oleh Sri Wahyuni (2010) bahwa ibu yang mengalami penurunan kadar $\mathrm{Hb}$ akan bersalin dengan operasi Caesar. Hasil penelitian menunjukan adanya pengaruh antara jenis persalinan terhadap penurunan kadar $\mathrm{Hb}$. Hal ini tentunya berdasarkan alasan tertentu yang pasti dengan tindakan persalinan tersebut dijadikan solusi terbaik untuk keselamatan ibu dan bayi, apapun yang menjadi kesulitan persalinan, penanganan selalu 
berpegang teguh pada prioritas keselamatan ibu dan bayi. Maka dalam rangka mengantisipasi adanya indikasi persalinan seperti penurunan kadar $\mathrm{Hb}$, maka ibu harus rutin memeriksakan kehamilannnya pada sarana kesehatan sehingga indikasi penurunan kadar $\mathrm{Hb}$ dapat di diagnosis lebih awal.

Pertolongan persalinan sangat penting namun pemeriksaan dan pengawasan ibu sewaktu hamil juga penting, akan banyak penyulit-penyulit ketika persalinan nanti. Bila ibu mengalami penurunan kadar $\mathrm{Hb}$ juga akan mengalami kesulitan saat bersalin, seperti rahim tidak berkontraksi dengan baik dan cepat lelah mengejan. Apabila hal ini terjadi, proses persalinan harus dibantu dengan vacum atau melalui operasi Caesar, maka hal ini sangat berpengaruh pada jenis persalinan. Jadi bisa tidaknya ibu hamil yang mengalami penurunan kadar $\mathrm{Hb}$ untuk melahirkan secara normal, tergantung dari kondisi ibu saat menjelang persalinan. Dan diperlukan persiapan dan perhatian lebih agar proses persalinan tersebut berlangsung dengan lancar. Salah satu usaha yang dilakukan misalnya dengan menyiapkan donor darah ketika proses persalinan untuk antisipasi kekurangan darah saat proses persalinan berlangsung. Tidak ada salahnya ibu hamil aktif bertanya mengenai kadar $\mathrm{Hb}$ dan tekanan darah saat hamil kepada Dokter kandungan saat melakukan pemeriksaan. Sebab apabila penyebab rendahnya kadar tersebut sudah benar-benar diketahui, maka pengobatan dan tindakan medis yang tepat pun bisa dilakukan menjelang persalinan.

Dari penelitian diketahui tidak ada pengaruh yang signifikan antara nilai IMT dengan penurunan kadar $\mathrm{Hb}$. Hasil ini tidak sesuai dengan teori Dian (2013) yang mengatakan bahwa Indeks massa tubuh (IMT) merupakan indikator yang paling sering digunakan untuk mendeteksi masalah gizi pada seseorang, karena hal itu dapat berpengaruh terhadap penurunan kadar $\mathrm{Hb}$ pada ibu bersalin. Sedangkan hasil penelitian disini menunjukkan tidak adanya pengaruh antara IMT dengan penurunan kadar HB. Penelitian ini tidak sesuai dengan penelitian yang dilakukan Yanti (2009) bahwa ibu dengan kejadian anemia memiliki hubungan yang bermakna dengan pola makan sewaktu hamil, tetapi hasil penelitian ini sesuai dengan hasil penelitian yang dilakukan oleh Sri Wahyuni (2010) yang menyatakan bahwa indeks massa tubuh tidak mempunyai hubungan yang signifikan dengan kadar $\mathrm{Hb}$ yang rendah.

Hasil penelitian menunjukkan bahwa IMT tidak ada pengaruhnya dengan penurunan kadar $\mathrm{Hb}$, tetapi perlu kita ketahui bahwa penurunan kadar $\mathrm{Hb}$ adalah masalah kesehatan dengan prevalensi tertinggi pada wanita hamil. Zat besi yang dibutuhkan sedikit karena tidak terjadi menstruasi. Menginjak trimester kedua dan ketiga, volume darah dalam tubuh wanita meningkat, sedangkan saat melahirkan wanita hamil butuh zat besi dua kali lipat dari kebutuhan zat besi pada kondisi tidak hamil. Penurunan kadar $\mathrm{Hb}$ pada kehamilan biasanya disebabkan oleh meningkatnya kebutuhan zat besi pada pertumbuhan janin, selain itu pola makanan ibu yang terganggu akibat mual pada kehamilan sehingga menyebabkan asupan zat besi ibu berkurang, oleh karena itu agar wanita hamil mau mengkonsumsi makanan dengan gizi seimbang sehingga dapat meningkatkan kadar $\mathrm{Hb}$ dalam darah. Penelitian ini tidak sesuai dengan penelitian sebelumnya, karena pada saat pengelompokan data yang dibuat penulis tidak mengelompokan data indeks massa tubuh ibu sesuai dengan kategorinya masing-masing, 
sehingga menyebabkan indeks massa tubuh tidak normal cenderung lebih besar.

\section{Simpulan}

Rata-rata kadar $\mathrm{Hb}$ sebelum persalinan adalah 11.62 gr\%, rata-rata kadar $\mathrm{Hb}$ sesudah persalinan adalah 11.01 gr\%, rata-rata penurunan kadar $\mathrm{Hb} 0.61$ gr\%, adanya pengaruh persalinan terhadap penurunan kadar $\mathrm{Hb}$, tidak ada pengaruh IMT terhadap penurunan kadar $\mathrm{Hb}$.

\section{Daftar Pustaka}

Ambarwati, E. 2008. Asuhan Kebidanan Nifas. Yogyakarta: Mitra Cendekia.

Arisman. 2007. Gizi Dalam Daur Kehidupan. Jakarta : Penerbit Buku Kedokteran.

Khaidir, M. 2009. Asuhan Keperawatan Dengan Infeksi Nifas. EGC: Jakarta.

Manuaba. 2012. IImu Kebidanan Penyakit Kandungan dan Keluarga Berencana. EGC: Jakarta.

Mika. 2012. Hubungan antara anemia dengan ibu bersalin di RB L tahun 2012. Yogyakarta.

Sarbaini. 2010. Faktor-faktor yang berhubungan persalinan Sectio Caesaria di RS IYG tahun 2010.

Soebroto, I. 2009. Cara mudah mengatasi problem Anemia. Yogyakarta: Bangkit.
Soekidjo, Notoatmodjo. 2010. Metodologi Penelitian Kesehatan. Rineka Cipta: Jakarta.

Sri Wahyuni. 2010. Hubungan anemia dengan kejadian persalinan premature di RS $P$ tahun 2010. Jakarta.

Suherni, dkk. 2008. Perawatan Masa Nifas. Yogyakarta : Fitramaya.

Sugiyono. 2007. Metode Penelitian Bisnis. Bandung. Pusat Bahasa Depdiknas.

Scanlon, vc dan sanders, T. 2007. Essensial of anatomi physiologi phila delphia,F.A davis company

Ulfatul Latifah, 2015. Hubungan antara anemia pada ibu bersalin dengan inpartu kala I lama di RSUD Dr.M.Ashari Kota Pemalang.

Prawirohardjo, Sarwono. 2012. Ilmu Kebidanan. Yayasan Bina Pustaka Sarwono Prawihardjo : Jakarta.

Rahma Dian. 2013. Hubungan Antara Indeks Massa Tubuh (IMT). Yogyakarta: Fitramaya.

Yanti. 2009. Pengaruh IMT pada wanita saat hamil terhadap pola makan di RSUP dr. K tahun 2009. Semarang. 